DOI: https://doi.org/10.36910/6775-2524-0560-2020-41-15

УДК 004.93

П'ятикоп Олена Євгенівна, к.т.н., доцент

https://orcid.org/0000-0002-7731-3051

Пучков Свген Едуардович, магістр

ДВНЗ «Приазовський державний технічний університет», м. Маріуполь, Україна

\title{
ОПТИМІЗАЦІЯ НАВАНТАЖЕННЯ МОБІЛЬНОГО ДОДАТКУ ВІДСТЕЖЕННЯ ОБ'ЄКТУ ПРИ ВИКОРИСТАННІ ДАТЧИКІВ МІСЦЕЗНАХОДЖЕННЯ
}

\begin{abstract}
П'ятикоп О.Є., Пучков Є. Е. Оптимізація навантаження мобільного додатку відстеження об'єкту при використанні датчиків місцезнаходження. Робота присвячена вирішенню питання оптимізації навантаження мобільного додатку з використанням датчиків мобільного пристрою. В статті наведено аналіз сучасного стану вирішення проблеми виявлення місцезнаходження об'єкту. Оскільки використання GPS суттєво впливає на ресурси мобільного пристрою, то запропоновано підхід з використанням Wi-Fi та стільникових веж. Проведено дослідження на прикладі системи відстеження школярів. Наведено опис процесів роботи системи та результати порівняння навантаження.

Ключові слова: мобільний додаток, служби локації, проблеми GPS, стільникові вежі, місцеположення, оптимізація навантаження.

Пятикоп Е.Е., Пучков Е. Э. Оптимизация нагрузки мобильного приложения отслеживания объекта при использовании датчиков местоположения. Работа посвящена решению вопроса оптимизации нагрузки мобильного приложения с использованием датчиков мобильного устройства. В статье приведен анализ современного состояния решения проблемы выявления местонахождения объекта. Поскольку использование GPS существенно влияет на ресурсы мобильного устройства, то предложен подход с использованием Wi-Fi и мобильных вышек. Проведено исследование на примере системы отслеживания школьников. Приведено описание процессов работы системы и результаты сравнения нагрузки.

Ключевые слова: мобильное приложение, службы локации, проблемы GPS, мобильные вышки, местоположение, оптимизация нагрузки.

Piatykop O., Puchkov Y. Optimization of a mobile application for tracking children using location sensors. The work is devoted to solving the issue of optimizing the load of a mobile application using sensors of a mobile device. The article analyzes the current state of the solution to the problem of identifying the location of an object. Since the use of GPS significantly affects the resources of a mobile device, an approach using Wi-Fi and cell towers is proposed. A study was carried out using the example of a tracking system for schoolchildren. The description of the system operation processes and the results of load comparison are given.
\end{abstract}

Keywords: mobile application, location services, GPS problems, cell towers, location, load optimization.

\section{Постановка наукової проблеми.}

Швидкий розвиток сучасних інформаційних технологій, мобільного та інтернет зв'язку, систем навігації поширив можливості сучасних мобільних пристроїв. Повсюдне поширення смартфонів значно змінило життя людей. У сучасних смартфонах і інших персональних електронних пристроях вбудовано багато датчики різного призначення. Також застосовуються технології інерціальної навігації, які раніше були доступні тільки авіаційній та космічній промисловості. Використання глобальних супутникових навігаційних систем дає все більше можливостей для визначення місцезнаходження в системах відслідковування рухомих об'єктів. Глобальна система позиціювання (GPS) забезпечує вимірювання відстані, часу і визначає місце розташування у всесвітній системі координат WGS 84. У мобільних додатках ця технологія використовується найчастіше для отримання навігаційних даних.

В даний час широкого застосування набули сервіси та мобільні додатки з функцією «GPSтрекінгу», завданням яких є відстеження маршрутів спостережуваних об'єктів з метою їх збереження та подальшого відтворення і аналізу. Наприклад, в статті [1] представлено використання служба місцеположення (Location-based services (LBS) в мобільних додатках для сфери маркетингу.

Однак через похибки GPS-датчиків, обумовлених певними причинами, такими як: втрата сигналу від супутника, зміна геометрії розташування супутників, відхилення сигналів, обчислювальні помилки і помилки округлення, більш детальне описання існуючих недоліків наведено в статті [2].

Одна з найбільших проблем у використанні GPS-технології пов'язана перш за все з помилками, які привносить приймач GPS-сигналу. Основною з цієї групи помилок є помилка годинника GPSприймача. Помилка GPS-приймача набагато більша у порівнянні з помилкою годинника супутника, тому як стабільність годинника приймача становить близько 1×10-10 на добу [3]. Тому поправка до показань годинника приймача повинна розглядатись як невідома величина.

Незважаючи на недоліки використання GPS при розробці мобільних додатків, ця технологія на сьогодні залишається найточнішою та найпоширенішою в області визначення поточних координат, принаймні в умовах відкритого простору. 
У зв'язку з постійним ростом інтересу використання в мобільних додатках навігаційних систем і служб локації, з'являються певні труднощі в реалізації подібного роду додатків.

Мобільні додатки, що використовують служби локації, регулярно взаємодіють зі своїм галасливим та постійно мінливим фізичним середовищем. Принципово невизначений характер таких взаємодій призводить до значних проблем в оптимізації навантаження на пристрій.

Стабільна робота такого додатка залежить від постійного використання служб локації, що істотно знижує термін життя акумулятора мобільного пристрою. Термін життя акумулятора - це найважливіший аспект взаємодії користувача 3 мобільним пристроєм. Пристрій без живлення взагалі не пропонує ніяких функціональних можливостей. В результаті експерименту, описаного в статті [4], проведеного у 2016-му році на прикладі телефонів Samsung Galaxy Note 3 та Sony Xperia Z2, стало відомо, що обрані пристрої втрачають $13 \%$ заряду в годину в місцях впевненого прийому сигналу GPS, та $38 \%$ в будівлі з залізним дахом.

3 цієї причини надзвичайно важливо, щоб програми максимально поважали час автономної роботи, використовували якомога менше ресурсів пристрою, самостійно контролювали навантаження та кількість переданих даних. Саме вирішення таких проблем $€$ важливою задачею в розробці програмного забезпечення для мобільних пристроїв.

Робота присвячена розробці та оптимізації мобільного додатку відстеження школярів 3 використанням служб локації.

Метою роботи $є$ зменшення навантаження мобільного додатку на ресурси мобільного пристрою, що споживаються в процесі роботи додатку.

Аналіз останніх досліджень і публікацій.

Для виконання на мобільних пристроях все більш складних додатків потрібні: збільшення ємності батареї і оптимізація процесів витрачання енергії. Отже, якщо перше залежить від виробників мобільних пристроїв, то другий аспект необхідно враховувати безпосередньо розробникам мобільного додатка.

При розробці навігаційного додатку існує проблема вибору методу локалізації та навігації рухомих об'єктів. Необхідно враховувати множину факторів: як уникнути проблем з визначенням поточної локації, не втрачаючи точність даних, якого маршруту потрібно дотримуватися, як зберегти точність визначення в умовах перебування в мегаполісі або в місцях погано сигналу GPS/GNSS та ін.

У зазначеної роботі [5] пропонується використання технології iBeacon (Apple) для локалізації рухомих об' єктів. iBeacon представляє собою API сервісів iOS, починаючи 37 версії, який дозволяє передачу даних між бездротовими пристроями, та пристроями, що підтримують Bluetooth LE. Детальний опис технології iBeacon наведено у статті [6].

Зазначена вище технологія разом з датчиком акселерометра мобільного пристрою, створюють, так званий, комбінований метод локалізації рухомих об'єктів. Сутність методу полягає в отриманні поточного місцезнаходження рухомого об'єкту всередині приміщення за допомогою передатчиків iBeacon, базуючись на міцності сигналу, що приймається, та корегування точності, використовуючи дані акселерометра. Вирішення питання направлення руху об'єкту полягає в скануванні всіх оточуючих передавачів. Той передавач, потужність сигналу від якого зменшується більше за інших, передбачається як опорний, тобто той, у бік якого рухається об' єкт. В наслідок цього з'являється можливість реалізувати компас з відносними сторонами світла. Зазначений підхід пропонується, як альтернатива використання інших джерел отримання поточного місцезнаходження, таких як: Wi-Fi, Bluetooth або GPS.

Пропонована в [7] система для визначення поточного місцеположення включає в себе три модулі: навігація, заснована на Wi-Fi мережах, PDR (Pedestrian Dead Reckoning), та EKF (Extended Kalman Filter) навігації.

При застосуванні EKF, дані з датчиків гіроскопа та акселерометра використовуються для визначення курсу рухомого об' єкту [8]. Отримані дані з'єднуються з результатами рішень Wi-Fi та технології мікроелектромеханічних систем (MEMS) для отримання кінцевого результату поточного місцезнаходження. Авторами [8] для оцінки ефективності цієї системи навігації було проведено ряд експериментів. Експериментальною платформою в даному випадку може бути будь-який смартфон на базі операційної системи Android, в якому встановлено відповідні датчики. В результаті експерименту, проведеного на дев' ятому поверсі блока «С» головного будинку університету Бейхан, були отримані наступні результати роботи алгоритму: максимальна помилка Wi-Fi/MEMS дорівнює 1,2498 м, що складається з 16\% від MEMS та 23,97\% від Wi-Fi; середня помилка дорівнює 0,6835 м, що складається 3 24,67 від MEMS та 36,25\% від Wi-Fi; середне квадратичне значення помилок визначення місцеположення дорівнює 0,7926 м. Таким чином, алгоритм Wi-Fi/MEMS на базі EKF, має достатньо велику точність оцінки, низьку обчислювальну складність та нетривалий час роботи. 
Інша робота [9] демонструє використання алгоритме визначення поточного місцезнаходження IPSCL, який складається з двох етапів. На першому етапі установки, IPSCL створює список автономних точок прив'язки та попередньо визначених орієнтирів. Точка прив'язки розглядається, як начальна точка позиціонування в приміщенні, наприклад, вхід до будівлі. Орієнтир в такому випадку - це положення, яке необхідно розглядати, як опорну точку. На етапі локалізації IPSCL вираховує положення користувача за допомогою гіроскопа та магнітометра, базуючись на характеристиках їх значень. IPSCL також коректує положення користувачів на основі орієнтирів та дозволяє додати місцеположення, в якому вони неодноразово виявляють той самий спеціальний RS датчик (Beacon RS). Коли користувач IPSCL входить в будівлю та сигнал GPS зникає, починається вимірювання значення RSSI датчиків Bluetooth в поточному положенні та отримання списку точок прив'язки с сервера. IPSCL виконує пошук найближчої точки прив' язки, яка має аналогічні списки точок доступу по К-алгоритму найближчого сусіда $(\mathrm{KNN})$. Як тільки користувач IPSCL знаходить найближчу опорну точку, він вибирає місцеположення, як початкову точку позиціонування в приміщенні та починає отримувати локацію в приміщенні. Після того, як початкова точка визначена шляхом пошуку опорних точок, система використовує вбудовані датчики смартфона для вимірювання руху користувача. По-перше, IPSCL виявляє кроки користувача за допомогою лічильника кроків. Лічильник кроків використовується для підтвердження того, чи користувач рухається, і це значення визначається шляхом вимірювання зміни показань датчика прискорення. Коли IPSCL виявляє крок користувача, він обчислює два значення для відстані та напрямку руху. Відстань - це значення, яке підтверджує, як довго користувач рухається. Напрямок курсу - це значення, яке підтверджує, в якому напрямку рухається користувач [8].

Тестування алгоритму проводилось в інженерному корпусі університету Сонмун [8]. Розміри місця становили 14,88 м $\times 21,86$ м $(325,27$ м2). В середньому для проходження стежки потрібно 57 с. Для експерименту було використано пристрій Samsung Galaxy A5 (2017), який включав датчик прискорення, датчик обертання та магнітний датчик. Для Bluetooth було використано датчик MiniBeacon 33 В батареєю CR2477. Результати тестування продемонстрували переваги використання технології IPSCL перед іншими відомими технологіями визначення місцезнаходження в приміщенні.

\section{Виклад основного матеріалу й обгрунтування отриманих результатів дослідження.}

Грунтуючись на результатах проведеного аналізу, огляду існуючих методів визначення поточного місцезнаходження, проблем і недоліків існуючих засобів, було розглянуто кілька варіантів реалізації визначення поточного місцезнаходження.

Сучасні системи позиціонування для точного визначення поточної локації, нерідко використовують вбудовані сенсори, в основному: акселерометр, магнітометр і гіроскоп. За допомогою використання цих сенсорів, формується траєкторія руху мобільного об'єкта. Однак, використання вищезгаданих сенсорів в смартфонах, не вдаючись до використання додаткових зовнішніх датчиків, отримання поточних координат стає важкодоступним. Тому уточнення поточного місцезнаходження проводиться шляхом використання сукупності вхідних даних, таких як:

- дані, отримані з інерційних датчиків;

- дані, отримані від найближчих стільникових веж (станцій);

- дані мереж Wi-Fi;

- дані, отримані іншими додатками, які недавно запитували локацію.

Грунтуючись насамперед на головній проблемі, виявленої в результаті аналізу наукової проблеми, були розглянуті різні варіанти оптимізації навантаження на акумулятор мобільного пристрою.

В якості першого варіанту була розглянута можливість застосувати метод трилатерації на основі даних о найближчих стільникових вежах щоб отримати поточні координати користувача. Для реалізації такого алгоритму, необхідно перш за все знати точне місце розташування стільникових веж. Для збору даних використовувався сторонній додаток. Зібрана інформація завантажувалася в відкриту базу стільникових веж «OpenCellID». Однак, в ході проведення збору даних, а також тестування визначення найближчих стільникових станцій, було знайдено кілька проблем, які зробили в деякій мірі неможливим реалізацію наміченого алгоритму. Головна проблема полягала в забороні отримання інформації про вежі, до яких мобільний пристрій не приєднаний в даний момент часу. Таким чином, користуючись в конкретний момент часу лише певним постачальником стільникового зв'язку, отримати інформацію про розташування усіх інших вишок проблемно. А точність визначення локації сильно залежить від кількості і типу стільникових веж. Також, для стабільної роботи алгоритму, необхідно мати або базу даних з інформацією про стільникові вежі, або здійснювати запит в відкриту базу даних «OpenCellID». Враховуючи частоту формування та відправки таких запитів, кількістю переданих даних, оптимізація додатка виявляється під питанням.

(С) П’ятикоп О.Є., Пучков Є. Е. 
Тому, було обрано інший підхід оптимізації, який полягає в отриманні поточної локації користувача шляхом використання в сукупності датчиків мобільного пристрою, точок доступу Wi-Fi i мобільних мереж.

При реалізації визначеного алгоритму, необхідно визначити послідовність процесів, які повинні відбуватися у додатку. Зображена на рисунку 1 діаграма демонструє послідовність процесів та етапи життя об’ єктів в процесі виконання додатку. При першому запуску, додаток перевіряє наявність токена - унікального ідентифікатора користувача в системі. У разі відсутності, додаток пропонує пройти реєстрацію, після чого автоматично генерує токен та зберігає в налаштуваннях додатку.

На наступному етапі додаток перевіряє наявність дозволів на використання служб локації мобільного пристрою, якщо додаток має необхідні дозволи, перевіряє доступність служб локації, якщо локація працює - додаток створює запит на отримання навігаційних даних, отримані дані передаються на сервер, сервер оновлює або додає запис в базу даних, користувач отримує поточні координати.

Якщо додаток не має необхідних для роботи дозволів, користувачу буде запропоновано надати їx, у разі відмови користувач отримує відповідне повідомлення, додаток запропонує знов. Якщо служби локації недоступні, користувачу буде запропоновано включити їх, у разі відмови користувач отримає повідомлення, щодо неможливості роботи додатку без наявності включених служб локації.

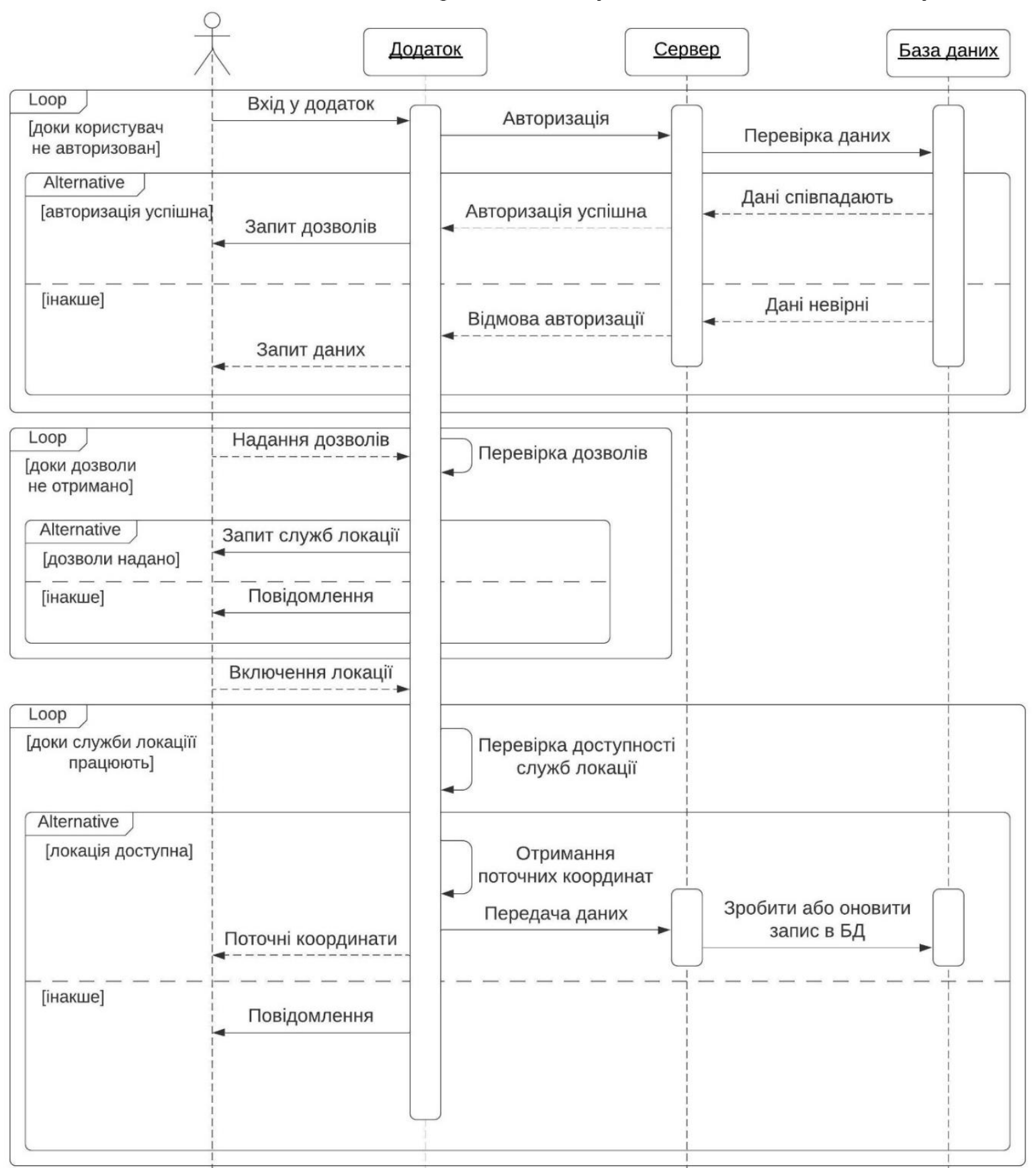

Рисунок 1 - Діаграма послідовності процесів, які відбуваються в додатку 
Мобільний додаток, на прикладі якого проводилось дослідження зменшення навантаження на ресурси мобільного пристрою, є частиною системи відстеження школяра для батьків. У системі $\epsilon$ мобільний додаток, що встановлено у батьків. Він повідомляє родичам про місцезнаходження дитини, наприклад у школі. На мобільному пристрої дитини встановлено інший мобільний додаток, який повинен передавати локалізацію дитини. Саме проблемі навантаження на цей пристрій присвячено дослідження. Схема взаємодії основних модулів системи показано на рисунку 2 , а діаграма розгортання зображена на рисунку 3.

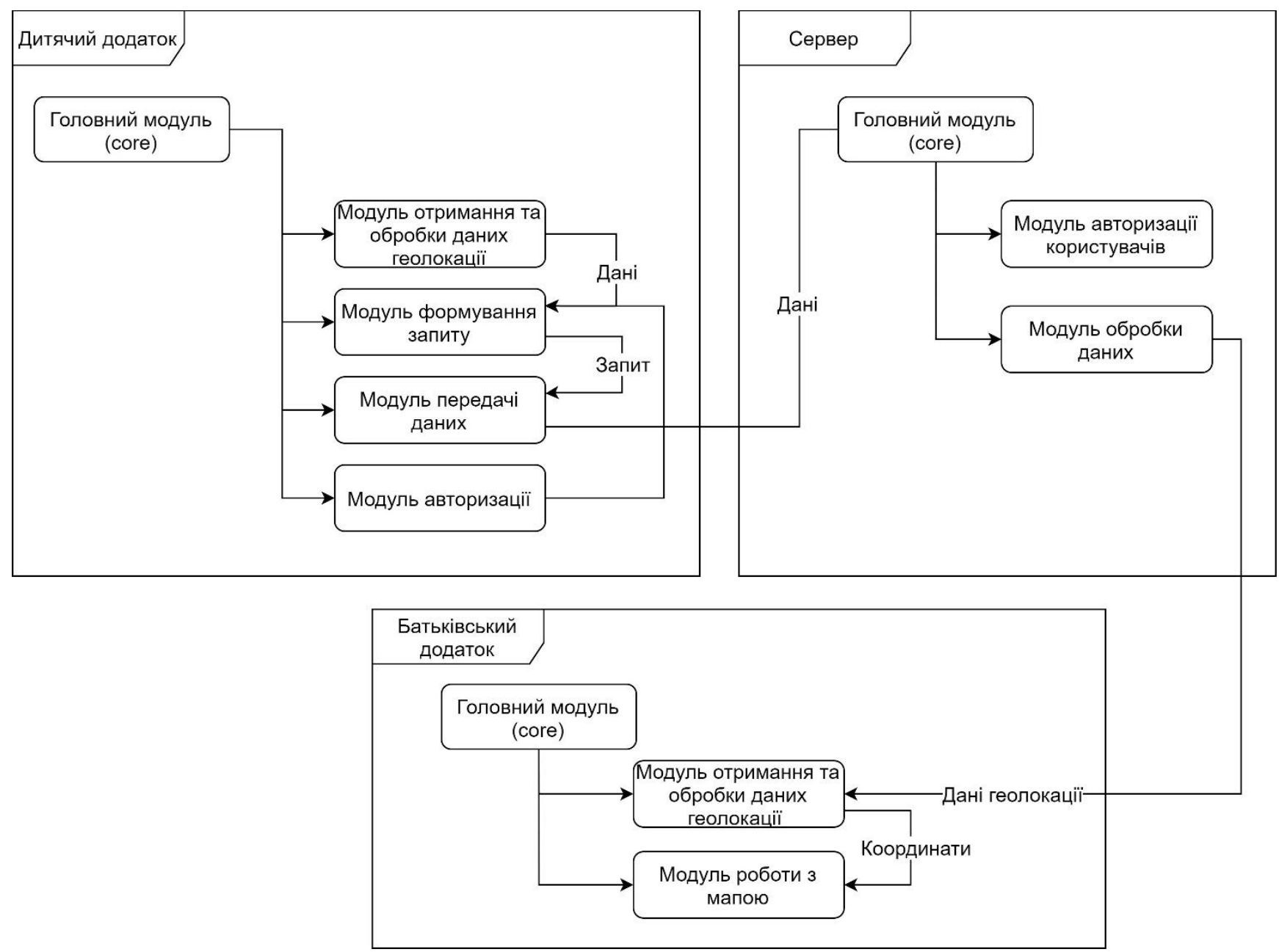

Рисунок 3.2 - Взаємодія модулів системи

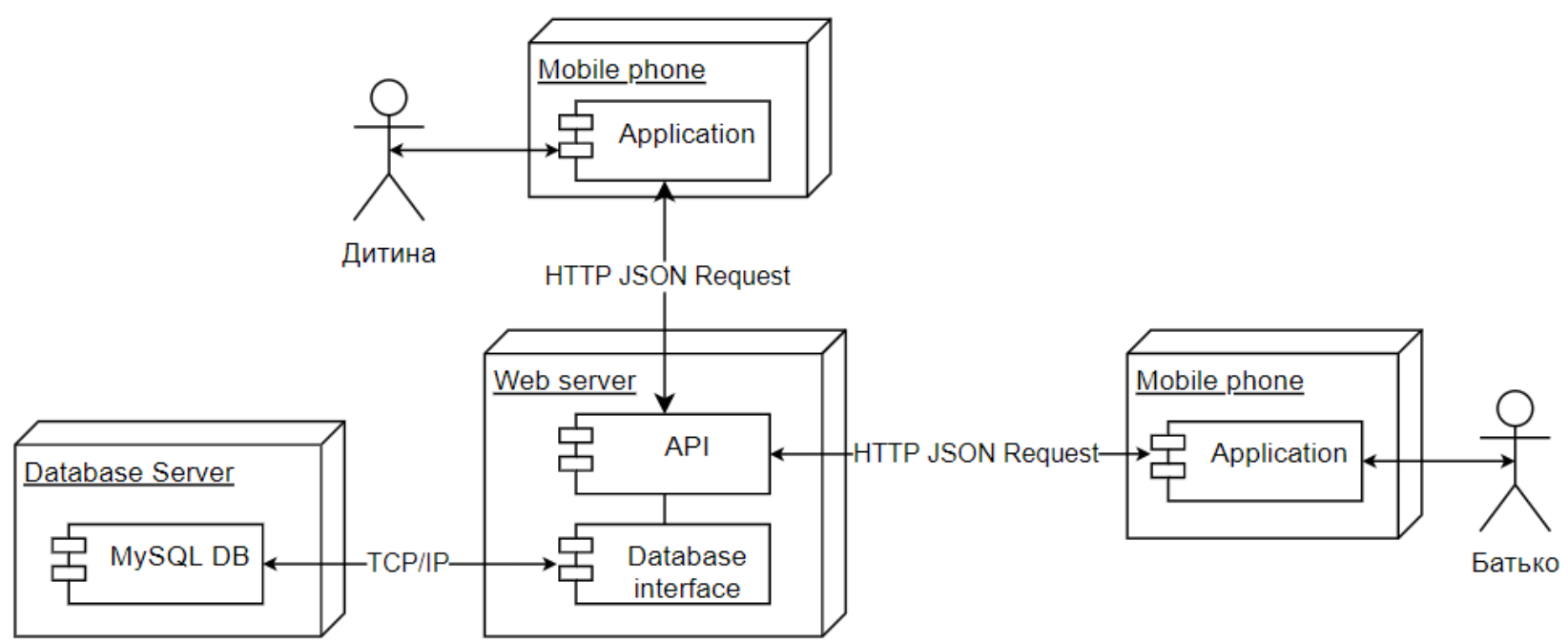

Рисунок 3 - Діаграма розгортання системи відстеження школярів. 
Експеримент проводився на мобільному пристрої HUAWEI CAN-L 11, з ємністю акумулятору 3020 мА/год, версія OC Android 7.0, підтримка стандартів зв’язку GSM, HSDPA та LTE. Пристрій використовує дві сім-карти мобільного оператору «Vodafone», відповідно GSM та LTE типу.

Результати оцінки навантаження додатку на ресурси мобільного пристрою, 3 використанням алгоритму оптимізації у зрівнянні з використанням GPS, приведено у таблиці 1.

Аналізуючи результати тестування додатку, можна зробити висновок щодо використання певного режиму в певних умовах. Режим локації «Найбільшої точності» використовує усі доступні джерела отримання даних, у тому числі GPS, саме використання GPS створює найбільше навантаження на акумулятор мобільного пристрою $(27,79$ мА/год за 30 хв). В залежності від умов, наприклад: перебування в будівлі з товстими стінами, або залізним дахом, в печерах або підземних переходах, метро тощо, місцях слабого сигналу GPS, навантаження може зростати. GPS видає максимальну точність визначення локації (від 1 до 3 м), в умовах відкритого простору, в більш важких умовах точність може варіюватися від 3 до 100 м (за даними тестування, проведеного в рамках цієї роботи).

Таблиця 1. Оцінка навантаження додатку

\begin{tabular}{|l|c|c|}
\hline \multicolumn{1}{|c|}{ Режим роботи } & GPS & Wi-Fi + Стільникові вежі \\
\hline Показник & $27,79 \mathrm{MA} /$ год & $5,16 \mathrm{MA} /$ год \\
\hline Енергоспоживання & $30 \mathrm{xB}$ & $<1 \mathrm{c}$ \\
\hline Тривалість роботи GPS & $<1 \mathrm{c}$ & $<1 \mathrm{c}$ \\
\hline Тривалість роботи Wi-Fi & $25 \mathrm{c}$ & $15 \mathrm{c}$ \\
\hline Використано часу ЦП (фон. реж.) & $1-100 \mathrm{M}$ & $5-150 \mathrm{M}$ \\
\hline Точність даних (радіус) & $215 \mathrm{KБ}$ & $301 \mathrm{KБ}$ \\
\hline Використання пам’яті (середнє) & $51 \mathrm{MБ}$ & $67 \mathrm{MБ}$ \\
\hline Використання пам'яті (максимальне) & $7,12 \mathrm{MБ}$ & $31,26 \mathrm{MБ}$ \\
\hline Фізичний розмір (усього) & & \\
\hline
\end{tabular}

Також, було проведено тестування точності визначення поточної локації. В умовах пішого пересування, максимальне значення відхилення від реального маршруту в цьому випадку склало 38,3 метрів. Якщо розглядати застосування мобільного додатку для перевірки локалізації дитини на території школи, то така відстань не перевищує прилеглого простору учбового закладу.

Проведена оптимізація істотно зменшує навантаження на акумулятор мобільного пристрою, 5,22 мА/год в порівнянні 27,79 мА/год, але точність отримання даних в залежності від складності умов може варіюватись від 5 до 40 метрів.

\section{Висновки та перспективи подальшого дослідження.}

Розвиток мобільних технологій і вдосконалення технологічних процесів ведуть до зменшення розмірів і збільшення потужностей мобільних пристроїв, появи переносної електроніки, оснащеної різними датчиками, в тому числі систем навігації. У зв'язку з цим виникає ряд нових напрямів застосування смартфонів та їх оптимального застосування. Так актуальною задачею для родичів $\epsilon$ відстеження місцезнаходження школяра за допомогою відповідних мобільних додатків. При цьому при застосуванні GPS виникає навантаження на ресурси смартфону, на сам перед на акумулятор.

Результатом проведеної роботи стало розроблення системи відстеження школяра, яка складається з дитячого, батьківського мобільних додатків та серверної частини. При цьому мобільний додаток дитини працює з використанням Wi-Fi та стільникових веж. Проведені експерименти показали позитивні результати застосування алгоритму оптимізації навантаження до вихідного додатку. Точність отриманих навігаційних даних, в контексті даної роботи, задовольнила поставленим вимогам. В майбутньому планується застосування також високоточних інерціальних датчиків.

\section{Список бібліографічного опису}

1. Suzan Girginkaya Akdağ \& Ahu Ergen (2020) Role of location-based mobile apps in city marketing: Beşiktaş as a studentfriendly district, Journal of Location Based Services, 14:2, 49-70, DOI: 10.1080/17489725.2020.1788184

2. Junbo Shi, Yongshuai Huang, Chenhao Ouyang, Xingning Lu \& Chaoqian Xu (2020) BeiDou/GPS relative kinematic positioning in challenging

3. Бутаков Н. А. Применимость инерциальной навигации в мобильных устройствах//Intern. Journal of Open Information Technologies. 2014. Vol. 2. N 5. P. 24-32.

4. Mohammad Tawalbeh, Alan Eardley, Lo'ai Tawalbeh, Studying the Energy Consumption in Mobile Devices, Procedia Computer Science, Volume 94, 2016, P. 183-189.

5. Рустинов В. А. Комбинированный метод локализации подвижных объектов / В. А. Рустинов, А. Р. Сорокин // Радиоэлектроника и информатика. - 2014. - №№4(67). - С. 83-88. 
6. Ye, Nuanqiang \& Luo, Jinman \& Zhao, Shanlong \& Yan, Jing. (2020). Application of Ibeacon in Indoor Positioning and Navigation. Journal of Physics: Conference Series. 1575. 012056. DOI: 10.1088/1742-6596/1575/1/012056.

7. Cui, Y.; Zhang, Y.; Huang, Y.; Wang, Z.; Fu, H. Novel WiFi/MEMS Integrated Indoor Navigation System Based on TwoStage EKF. Micromachines 2019, 10, 198.

8. Apráiz, Matilde \& Diego, Ramón \& Barros, Julio. (2018). An Extended Kalman Filter Approach for Accurate Instantaneous Dynamic Phasor Estimation. Energies. 11. 2918. DOI:10.3390/en11112918.

9. Jang, B.; Kim, H.; Kim, J.W. IPSCL: An Accurate Indoor Positioning Algorithm Using Sensors and Crowdsourced Landmarks. Sensors 2019, 19, 2891.

10. Миниахметов Р. М., Обзор алгоритмов локального позиционирования для мобильных устройств // Р. А. Миниахметов, А .А. Рогов, М .Л. Цымблер URL: https://cyberleninka.ru/article/n/obzor-algoritmov-lokalnogopozitsionirovaniya-dlya-mobilnyh-ustroystv.

\section{References}

1. Suzan Girginkaya Akdağ \& Ahu Ergen (2020) Role of location-based mobile apps in city marketing: Beşiktaş as a studentfriendly district, Journal of Location Based Services, 14:2, 49-70, DOI: 10.1080/17489725.2020.1788184

2. Junbo Shi, Yongshuai Huang, Chenhao Ouyang, Xingning Lu \& Chaoqian Xu (2020) BeiDou/GPS relative kinematic positioning in challenging

3. Butakov N. A., Applicability of inertial navigation systems in mobile devices (2015) International Journal of Open Information Technologies, ISSN: 2307-8162 vol. 2, no. 5

4. Mohammad Tawalbeh, Alan Eardley, Lo'ai Tawalbeh, Studying the Energy Consumption in Mobile Devices, Procedia Computer Science, Volume 94, 2016, p. 183-189, ISSN 1877-0509

5. Rustinov V. O., Sorokin A. R., Combined method of localization of moving objects, Radioelectronics and Informatics, no. 4 (67), 2014, pp. 83-88.

6. Ye, Nuanqiang \& Luo, Jinman \& Zhao, Shanlong \& Yan, Jing. (2020). Application of Ibeacon in Indoor Positioning and Navigation. Journal of Physics: Conference Series. 1575. 012056. DOI:10.1088/1742-6596/1575/1/012056.

7. Cui, Y.; Zhang, Y.; Huang, Y.; Wang, Z.; Fu, H. Novel WiFi/MEMS Integrated Indoor Navigation System Based on TwoStage EKF. Micromachines 2019, 10, 198.

8. Apráiz, Matilde \& Diego, Ramón \& Barros, Julio. (2018). An Extended Kalman Filter Approach for Accurate Instantaneous Dynamic Phasor Estimation. Energies. 11. 2918. DOI:10.3390/en11112918.

9. Jang, B.; Kim, H.; Kim, J.W. (2019) IPSCL: An Accurate Indoor Positioning Algorithm Using Sensors and Crowdsourced Landmarks. Sensors 2019, 19, 2891. 